\title{
INTERTWINED WORLD: ECONOMIC NETWORKS, Positionality AND GROWTH
}

\author{
TENZIN TAMANG ${ }^{*}$, HOAN PHUNG TIEN**
}

\begin{abstract}
Deepening globalisation and the unrestricted flow of resources across domestic borders has led to the emergence of an intertwined world, which has replaced the influence of local to global forces on places. In this situation, there has been an advent of a network paradigm, as understanding how nations are placed within these networks has become critical in 'globalizing' policies. Although literature posits that the fate of places has become increasingly reliant to their position in networks shaped by the international flows of investment and trade, this is more often asserted than demonstrated, as little studies probes on whether positionality of nations in a network directly converts to improved economic performance. Drawing upon data on Foreign Direct Investments (FDI) from financial times, in this paper we test the relationship between network positionality in different scales of integration and economic performance between 2003 and 2016 for the Southeast Asian countries.
\end{abstract}

Keywords: Globalization, Networks, Positionality, Economic growth, Foreign Direct Investment (FDI), Southeast Asia.

JEL Classification: $D 85, F 21, F 63$

\section{INTRODUCTION}

Deepening globalisation and the unrestricted flow of resources in the form of capital, goods and services across domestic borders has led to the emergence of an intertwined or a networked world, which has replaced the influence of local to global forces on places (Clark et al. 2002). Hence, places today are like any other complex structures which are increasingly reliant on interdependencies, realised through complex linkages (Schweitzer et al. 2009). It is argued by scholars that in this scenario 'networks' has grown into foundational units of analysis to better understand

\footnotetext{
* Tenzin Tamang (Corresponding author), Erasmus University Rotterdam, The Netherlands, Senior Analyst, LT Associates, Thimphu Bhutan, e-mail: teny606@gmail.com *** Hoan Phung Tien, Erasmus University Rotterdam, The Netherlands, data analyst, Nelen \& Schuurmans, The Netherlands, e-mail: hoanphung.cpo@gmail.com
} 
the global economy, rather than firms and places (Dicken et al. 2001); calling for a fresh methodology to go beyond the limits of established knowledge and theories on the driving forces of development. In this situation, there has been an advent of a network paradigm and the use of various network exploration tools to understand the role of cities/nations as actors within networks shaped by the inter-country flow of various resources, as understanding how nations are placed within these networks has become critical in 'globalizing' policies (Clark et al. 2013).

The initial concept of network economies were perceived as early as the $20^{\text {th }}$ century when the internationalization of economies bloomed. Studies like 'Cities as Systems within Systems' by (Berry 1964) were grounded in the concept that cities encompassed both internal and external relations. Further, (Hall 1966) in his book, 'World Cities', posit the need to take account of the external relationship of cities to understand how they develop. However, the initial concepts were relatively simple and hierarchical (Taylor 2004). The current strands of studies on networks between economies were provided with a starting point by the World City Hypothesis by (Friedmann 1986). His work provided the early concept of the spatial organization of the new international division of labour. He argued that certain cities would take a central position in the organization of markets and capital, while their subsidiaries would arrange into a system forming a global hierarchy. These cities would control international finance also acting as a key destination for both investments and human capital (Friedmann 1986). Since then several strands of literature by eminent scholars like (Camagni and Salone 1993, Sassen 1994, Castells 1996) have theorized the concept of networks. However, the first thorough empirical analysis on networks between cities was demonstrated by (Taylor 2004) in his book World City Network, which emphasized on the emergence of new networks formed by major financial and business service firms and their global clients.

Building on this, a body of related empirical research on places has emerged investigating various networks. Some of this includes studies on global infrastructure networks such as airline passenger networks (Smith and Timberlake 2001), corporate networks formed by multinational headquarters and their subsidiaries (Alderson and Beckfield 2004, Wall 2009) and economic linkages through the Australia-based corporate network (Sigler and Martinus 2017). This brief overview of networks between economies was aimed to reveal the conception of networks over time. Broadly, the core of all this studies efforts to explain how technological advances have led to the reduction of local barriers expanding activities and interactions beyond national boundaries in the global space, forming 
physically unseen yet existing networks. Hence, in this scenario, the traditional paradigm of territories is replaced by networks.

\subsection{Originality/Value}

There is a considerable amount of research on cities/nations adopting a network approach, but mostly, they are focused on defining their role within diverse networks differentiated by functionality and are commonly discussed at a global scale, failing to consider that places are embedded in a range of geographical scales, from local to global as emphasized by (Sheppard 2002). Relatively, limited research has explored it across networks of different scale. Furthermore, the positionality of nations within a network is said to determine their power and prestige in the global system, but there is limited empirical evidence on whether it directly converts to improved economic performance (Pain et al. 2016), and if the positionality at different network scales has differential impacts on their performance.

Building upon existing research which is primarily based on the World City Network (WCN) research that has significantly theorized on the dynamics of global economic connectivity, this paper extends the limits of existing research: first, by adding a scalar perspective to positionality as equally important. The term 'positionality' herein describes how different nations are positioned concerning one another in a network. It is theorized as both moulding and moulded by the courses of globalization and as driving the growth of places in a globalizing world (Sheppard 2002). To our knowledge, only (Wall 2009) has explicitly assessed the scalar differences of positionality in intercity corporate networks covering corporate networks across the globe, corporate networks of Europe with their worldwide subsidiaries and corporate networks of The Netherlands with their worldwide partners.

Second, this study contributes to the literature by assessing the correlation between a nation's positionality in different network scale and their economic performance. This allows combining network data with attribute data of each country, as emphasized by studies like (Alderson and Beckfield 2004, Carroll 2007) on the need to account both network data and attribute data to make network research more significant to development studies. To our knowledge, only (Pain et al. 2016) has assessed the relationship between city network connectivity and economic performance. Using corporate connectivity in advanced producer services, air and maritime connectivity of US and European cities as network measures, they attempt to disentangle whether the position of cities in the network correlates to economic growth (GDP). Other closely related research on the topic 
has been conducted by (Wall 2009) evaluating the strength of corporate connectivity with the competitiveness of nations.

In analysing positionality and its association with economic growth, a scalar approach is important because with the division of large production units into multiple subsidiaries across different geographical scales (Dicken 2004) the spatial reach of nations has advanced and they tend to occupy diverse positions in different network scales (van der Knaap 2006). Further, various geographical scales may influence a city's competitiveness (Asheim and Isaksen, 2002) or may even simultaneously influence them (Malmberg and Maskell, 2002). Understanding of places and their development as a consequence of multiple relational assets and resources (Amin and Graham 1999) and considering the multiscalar forces that influence regional development and not favouring one specific spatial scale (Coe et al. 2004) may allow policymakers to frame correct or strategic interventions based on their priority or interest. Also, contemporary economic development studies have been bedevilled by analytical disjunctions, ensuing abstractions at either macro or meso levels or where empirical analysis have queried micro-level processes (Henderson et al. 2002).

The networks explored in this study concern the Foreign Direct Investment (FDI) linkages considering literature posit that the performance of nations/cities have been increasingly dependent on the position they occupy in networks shaped by international investments and trade (Alderson and Beckfield 2004). Further, FDI also is a significant attribute of the globalization era, observed as the movement of capital between countries, mostly from industrialised to developing countries (Hofmann 2013). By the year 2000, 40\% of investments to developing countries were in the form of FDI and from the year 1990 to 2011, FDI in the world's total GDP increased from $8 \%$ to $29 \%$ (Schwab 2014) highlighting the growing significance of FDI in the global economy.

As the networks explored in this study concerns FDI linkages, third, this study may also complement the discussion on the FDI and economic growth nexus. Although there is a plethora of work on foreign investment and economic growth, this tends to largely rely on traditional non-relational data as a proxy indicator for economic integration for its empirical bases. Little of it probes the network dimension of these investments and its impact on the economies, and even less of it deals with the significance of multi-scalar investment networks for economic development.

Unlike previous research which is skewed in their geographical focus with most extant studies focused on developed regions or is discussed globally, this 
paper provides empirical evidence from the ASEAN (Association of Southeast Asian Nations) region which has received little scholarly attention on this subject. The region also provides a fertile ground of research for this study because of its socio-economic conditions and associated policy challenges. The region experiences a highly uneven distribution of investment flows among nations of different economic levels.

Though most of the extant network studies are based on intercity linkages, this study is not executed at the city level because FDI data and most economic performance indicators at the city level for this region are not readily available. A national-level analysis is, however, justifiable considering that amid globalisation, cities have become the epicentre of the global economy and the role of nations may have declined but this does not mean they have become insignificant to the world economy (Taylor 2004).

First, this paper applies social network analysis to study the positionality of ASEAN countries at different scales of integration to generate multi-scalar network patterns and to analyze and compare them for deeper insights. The geographical scales explored in this study concerns: first, the FDI linkages between ASEAN and countries world-wide (global). The second concerns linkages between ASEAN and Asian countries (regional) and third includes the intra-ASEAN linkages (local). Three common network measures of centrality have been used to study the positionality. Second, three regressions for the global, regional and local scale is conducted to identify if their respective positionalities share a significant correlation with the economic performance. Five different measures of centrality are included in the regression to derive a refined understanding of the association between positionality and economic growth.

The next section provides the methodology. In section three, the empirical results are discussed, followed by a discussion in four and the conclusions in section five.

\section{Methodology}

The data used in the analyses concern bi-lateral Greenfield FDI linkages of the ten ASEAN countries compiled from Financial Times, fDI markets. FDI is primarily composed of 'Greenfield investments' and 'mergers and acquisition (M\&A)'. The interest of this study, however, is Greenfield FDI as it represents investments from multinationals to new subsidiaries and tends to directly support capital formation, transfers new technology, boosts innovation, productivity and employment (Shi et al. 2019). This provides a noticeable link between investment 
flows and a nation's economic performance. The compiled FDI data is for the period 2003 to 2016.

To investigate the positionality of ASEAN nations in their global, regional and local investment networks, social network analysis is applied which has become increasingly popular in city network studies (Alderson and Beckfield 2004, Derudder and Taylor 2005, Toly et al. 2012, Hennemann and Derudder 2014). While there are many tools to execute network analysis, this study applied Gephi network mapping to generate weighted network structures of the ASEAN investment linkages. In generating the maps, aggregate FDI data for the period is used. The representation of the countries in the figures is done with country codes. Table 1 below provides the list of countries included in the analysis with country codes.

Table 1: List of Countries and Codes

\begin{tabular}{c|c|c}
\hline No. & Country & Country Code \\
\hline 1 & Brunei Darussalam & BRN \\
\hline 2 & Cambodia & KHM \\
\hline 3 & Indonesia & IDN \\
\hline 4 & Lao PDR & LAO \\
\hline 5 & Malaysia & MYS \\
\hline 6 & Myanmar & MMR \\
\hline 7 & Philippines & PHL \\
\hline 8 & Singapore & SGP \\
\hline 9 & Thailand & THA \\
\hline 10 & Vietnam & VNM \\
\hline
\end{tabular}

Source: Authors, 2020

\subsection{Network Measures of Centrality/Positionality}

In the first part of the study, the positionality is analysed based on the total FDI flows occurred in the period. Three common network measures of centrality have been used to study the positionality of ASEAN countries in their global, regional and local investment network, namely indegree, outdegree, and betweenness. Fundamental to these measures is the notion that the positionality of the actors (nations) in the network is determined by the interaction between actors. In simpler terms, indegree refers to the number of incoming ties and outdegree signifies the number of outgoing ties from an actor. In city network literature, indegree is generally referred as an indication of prestige or dependency of a city on others and outdegree provides a measure of the economic power of city on others (Alderson and Beckfield 2004). Indegree and outdegree formula are as follows: 


$$
C_{I}\left(n_{i}\right)=\frac{x+i}{g-1} \quad C_{o}\left(n_{i}\right)=\frac{x i+}{g-1}
$$

In the formula (1), the indegree CI of country ni is the number of links received by country $\mathrm{i}$, is represented by $\mathrm{X}+\mathrm{i}$. Similarly, $\mathrm{g}-1$ represents the maximum number of ties linking $\mathrm{i}$ to $\mathrm{j}$. The outdegree $\mathrm{CO}$ of country ni is where $\mathrm{Xi}$ + represents the number of ties sent from country $i$, and $g-1$ is the maximum number of possible ties linking $i$ to $j$ (Wasserman and Faust 1994).

The third centrality measure explored in the study is the betweenness centrality which indicates the strength of the brokering role of actors in a network (Borgatti 2005). Places that are located in the connecting paths of other cities in the network are deemed to have a higher betweenness and will have the advantage of being brokers who control the flow of information, capital and trading activities in a network or even act as a 'bridge' to sub-networks (Neal 2013).

Betweenness formula:

$$
C_{B}\left(n_{i}\right)=\frac{\sum_{j<k} \frac{g_{j k}(n i)}{g_{j k}}}{(g-1)(g-2) / 2}
$$

The formula (2) shows how to calculate the betweenness CB of each country ni where $\mathrm{g} \mathrm{jk}(\mathrm{ni}) / \mathrm{g} \mathrm{jk}$ represents the probability that the geodesic $\mathrm{g}$ linking countries $\mathrm{j}$ and $\mathrm{k}$ include country $\mathrm{i}$. To standardize this it can be written as $(\mathrm{g}-1)(\mathrm{g}-2) / 2$ to guarantee that $C_{B}$ (ni) will be between 0 and 1 (Wasserman and Faust 1994).

For the second part of the analysis, three separate regressions were conducted to assess the correlation between the positionality of ASEAN countries in the investment network and their economic growth. In addition to the degree and betweenness centralities, two additional measures of centrality: closeness and eigenvector, were included in the regression as the independent variable. Unlike the study by (Pain et al. 2016) which uses the number of ties as a general indicator of network connectivity, this study takes account of five network measures of centrality in the regression to assess the relationship based on the different positionality of nations in the network. This is comparable to (Wall 2009) which included two measures of centrality (indegree and outdegree) and total connectivity as a measure of network strength for assessing the connectivity and competitiveness relationship.

Closeness centrality indicates the network proximity to near and distant nodes of the network and those with higher closeness scores tend to be at an informational advantage (Neal 2011). The idea of the eigenvector centrality is based on the notion that a node will be more central or prestigious if it shares a relationship with nodes that are highly central or prestigious, so the centrality of a 
node not only depend on the number of its connection with other nodes but also the weight or value of the associated nodes. Thus, this approach is ideally suitable for analysing the influence of a node within the network (Ruhnau 2000). Mathematical representation of closeness centrality is as follows:

Closeness centrality:

$$
C(n i)=\frac{1}{\sum_{y} d(y, x)} \times \mathrm{n}
$$

The formula (3) shows how to calculate the closeness $\mathrm{C}$ of each country ni. It is calculated as the reciprocal of the sum of the length of the shortest path between the country and all other countries in the network as denoted by $\sum y \mathrm{~d}(\mathrm{y}, \mathrm{x})$ where $\mathrm{d}(\mathrm{y}, \mathrm{x})$ is the distance between vertices formed by ties $\mathrm{x}$ and $\mathrm{y}$. In a normalized form, the formula is multiplied by $\mathrm{N}$ where $n$ is the number of nodes (actors) in the network.

In a network graph, if a country $i$ is connected to $j$, the eigenvector centrality score of country i can be calculated as follows, where $M$ (i) is the set of neighbours of country $i$ and $\lambda$ is a constant.

Eigenvector:

$$
C_{i}=\frac{1}{\lambda} \sum_{j \in M(i)} x_{j}
$$

\subsection{Empirical Model}

The Gross Domestic Product (GDP) data of the ASEAN countries for the period were compiled from the World Bank database and is used as the dependent variable in all three regressions. Since positionality is not the only factor that may impact the economic performance of a country, a set of indicators of human capital, institutional setting, infrastructural development, demography and market condition is included in the model as control variables.

Many studies have pointed human capital as one of the key factors that determine the economic performance of a country. It not only influences national production through labour productivity (Borensztein et al. 1998) but also facilitates the transfer of technology, new practices, and skills (Nguyen et al. 2009) fostering innovation. Availability of skilled and qualified human capital is also said to determine the competitive advantage of nations influencing the rate of foreign investments (Blomstrom and Kokko 2001). Hence, the analysis included two indicators of human capital in the regression analyses, namely education and employment rate as a measure of skills and workforce respectively. 
The institutional setting in the form of policies, coordination system or governance structure is also argued to be pivotal for achieving economic growth and improving the competitiveness of a country. Whitley (1998) posit that the nature of markets and behaviour of firms in a business system vary across geographical locations because of the differences in institutional settings that moderates the financial and labour markets (Whitley 1998). Also, Kitson (2004) consider institutional settings as social capital and a local asset that makes a region more competitive and provides common commitment which is favourable for firms and businesses (Kitson et al. 2004). Therefore, this analysis incorporated an indicator of corruption control as an indicator of the institutional setting.

Further, an indicator of liner shipping connectivity is included in the model as a measure of infrastructural development because studies have also claimed that the level of development of a country in terms of physical infrastructure closely links to their performance. Infrastructure like electricity, roads, and information technology improves the productivity of the local firms by reduction of cost (Le Blanc et al. 2016). Also, studies have found that the quality of physical infrastructure supports the human capital of a country and contributes to the pursuit of socially inclusive growth. It improves the productivity of the people by creating equal access to services like education and health that improve their abilities to pursue opportunities (Ali and Pernia 2003). Last, indicators of population density and inflation are also included in the model as a control for demographic size and market condition respectively. Table 2 below provides the details of variables, indicators included in the regression model and the data sources.

Table 2: Variables and indicators

\begin{tabular}{|c|c|c|}
\hline Variable & Indicator & Source \\
\hline Economic growth & GDP per capita & World Bank \\
\hline \multirow{5}{*}{ Network centrality } & In-degree & \multirow{5}{*}{$\begin{array}{l}\text { Generated using } \\
\text { network } \\
\text { analysis }\end{array}$} \\
\hline & Out-degree & \\
\hline & Betweenness & \\
\hline & Closeness & \\
\hline & Eigenvector & \\
\hline FDI & FDI value & FDI Market \\
\hline Education & $\begin{array}{l}\text { Educational level (\% enrolment } \\
\text { in tertiary education) }\end{array}$ & World Bank \\
\hline Labour & Employment to population ratio & World Bank \\
\hline
\end{tabular}




\begin{tabular}{l|l|l}
\hline \multicolumn{1}{c|}{ Variable } & \multicolumn{1}{|c}{ Indicator } & \multicolumn{1}{c}{ Source } \\
\hline Governance & Control of corruption & World Bank \\
\hline Infrastructure & Liner shipping connectivity & World Bank \\
\hline Population density & Population density & World Bank \\
\hline Inflation & Inflation rate & World Bank \\
\hline
\end{tabular}

Source: Authors, 2020

Before running the analysis, it was ensured that the model met the assumptions and following a Hausman test, the analysis adopted a fixed-effect model.

$$
\text { Yit }=\beta 1 X i t+\alpha i+\varepsilon i t
$$

In formula (5): $\mathbf{Y}_{\mathrm{it}}$ is the dependent variable with $\mathrm{i}=$ entity, $\mathrm{t}=$ time; $\mathbf{X}_{\mathrm{it}}$ is the independent variables; $\mathbf{B}_{1}$ is the coefficient of the independent variable; $\boldsymbol{\alpha}_{\mathrm{i}}$ is the intercept for each country; $\boldsymbol{\varepsilon}_{\mathrm{it}}$ is the error term.

\section{RESULTS}

\subsection{Positionality}

To recapitulate, the first part of this research concerns positionality of the ASEAN countries in the investment networks that link them to other countries and to compare the networks at different scales (global, regional and local). For this inquiry, the indegree, outdegree and betweenness centrality techniques are applied and network maps have been generated to assess the positionality of ASEAN countries in the network of investment flows through visual and topological representation. The ASEAN countries are represented as nodes (with country codes) connected through FDI linkages in the following Figures one, two and three below. The size of the dot representing each country is weighted and is proportional to the indegree, outdegree and betweenness of the countries (nodes).

In the results (Figure one), Indonesia is the dominant nation in terms of global indegree, followed by Singapore, Vietnam and Malaysia. Laos, Cambodia, Myanmar and Brunei are the least attractive destination for global investors in the ASEAN exhibiting trivial global indegree. Also, at a regional scale, Indonesia prevails as the leading nation in terms of indegree showing that it is the most attractive destination for Asian investors, followed by Vietnam. A visible difference between the global and regional indegree network is the dipping positionality of Singapore on the regional scale compared to global. On the other hand, Vietnam and Indonesia 
maintain a strong indegree even in the regional network. In the local indegree network, similar to their positions in the regional network, Indonesia is the leading nation followed by Vietnam. The indegree position of Singapore is found to be further reduced in the local network and is only comparable to Brunei, which has the least indegree in all scales of the network.

In the results (Figure two), the network-based on outdegree of the ASEAN countries in all the scales show a similar pattern, with Singapore as the standout nation. All the remaining nine ASEAN countries share insignificant outdegree compared to Singapore. However, following Singapore, Malaysia and Thailand tend to have relatively stronger outdegree centrality than other countries, in all the scales. In the results (Figure three), Singapore is the top nation in terms of betweenness, in the global and regional investment network. However, Vietnam holds the leading brokerage position in the intra-investment network despite its nominal position in the global and regional network, followed by Singapore. Countries like Thailand also hold a dominant betweenness position in all the networks, only second to Singapore in the global and regional network; and occupying the third position in the local network. 
Figure 1: Weighted indegree Centrality of the ASEAN countries (2003 - 2016)
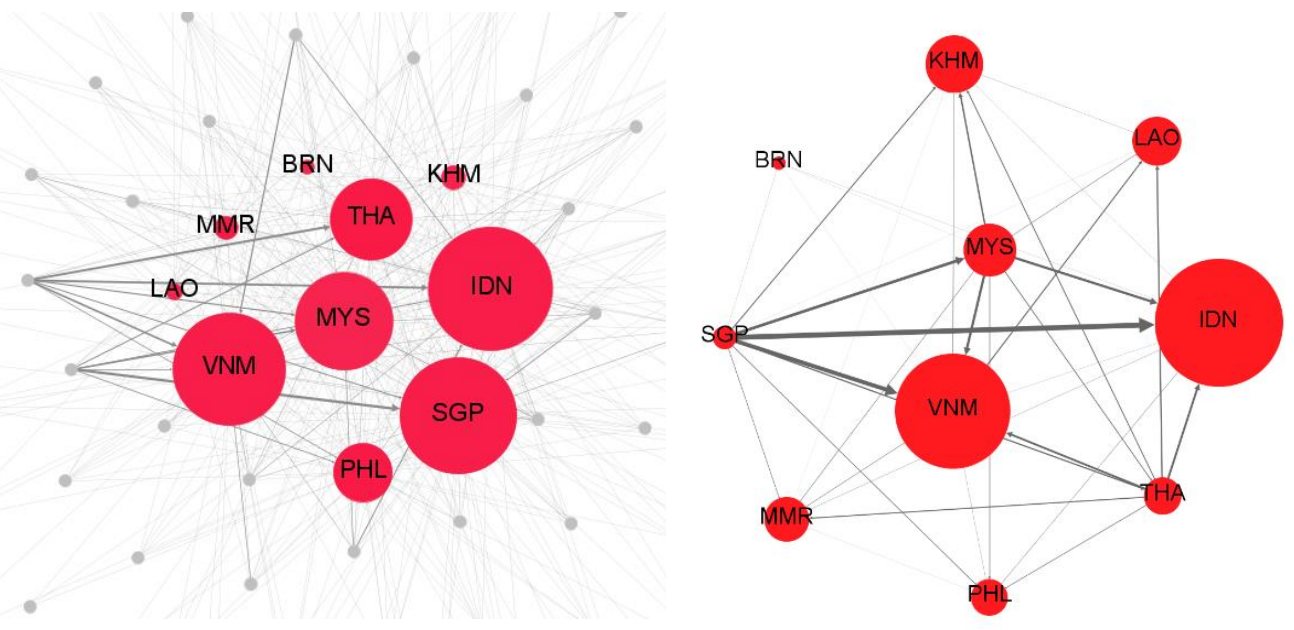

Global

Local

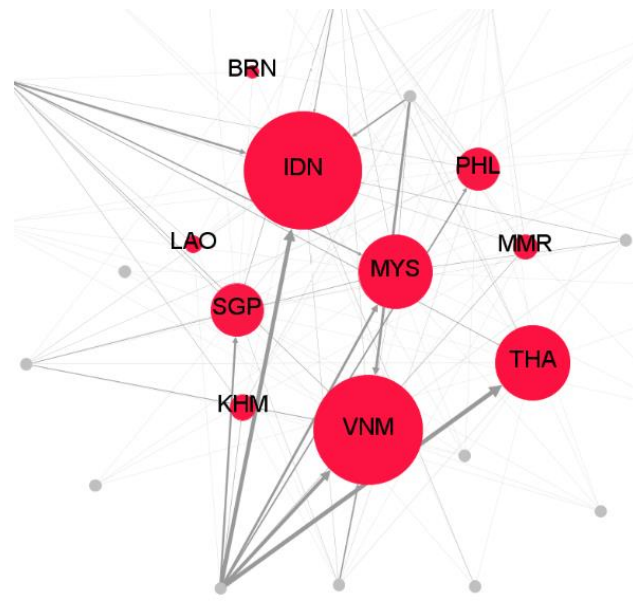

Regional

Source: Authors, 2020

\section{Figure legend}

The circles with codes represent the ASEAN countries connected by FDI flows. The size of the circle is weighted and is proportional to the indegree of the countries (nodes).

Country Codes: Brunei Darussalam-BRN; Cambodia-KHM; Indonesia-IDN; Lao PDRLAO; Malaysia-MYS; Myanmar-MMR; Philippines-PHL; Singapore-SGP; ThailandTHA; Vietnam-VNM

Indegree centrality shows how much a node is connected to others through incoming ties. Maps generated using Gephi Network Mapping 
Figure 2: Weighted outdegree centrality of the ASEAN countries (2003 - 2016)

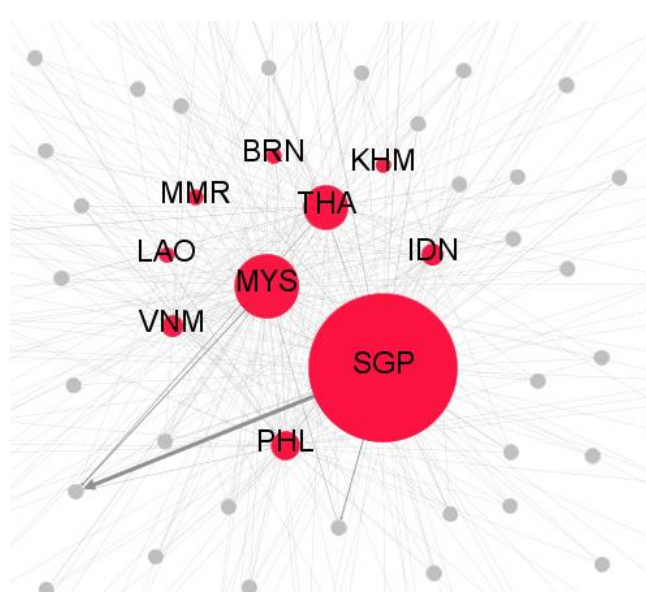

Global

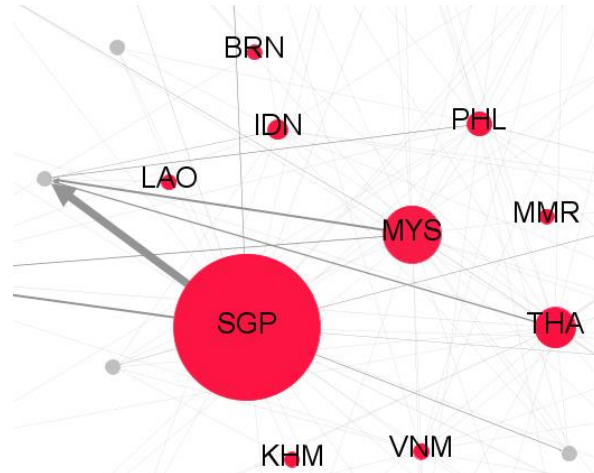

Regional

Source: Authors, 2020

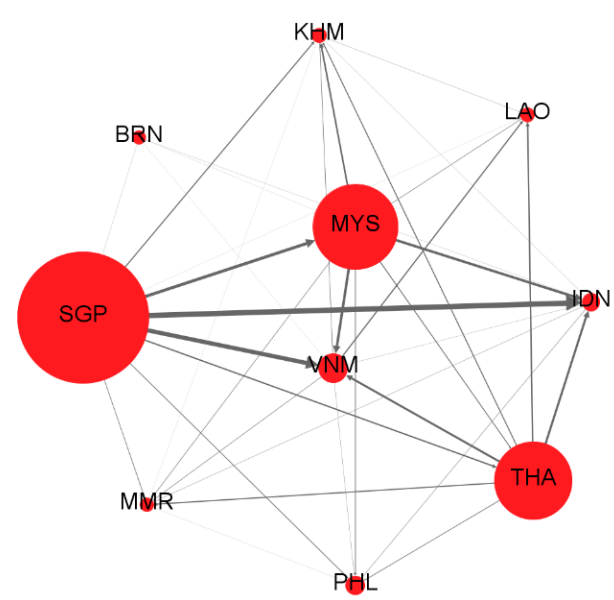

Local

\section{Figure legend}

The circles with codes represent the ASEAN countries connected by FDI flows. The size of the circle is weighted and is proportional to the outdegree of the countries (nodes).

Country Codes: Brunei Darussalam-BRN; Cambodia-KHM; Indonesia-IDN; Lao PDRLAO; Malaysia-MYS; Myanmar-MMR; Philippines-PHL; Singapore-SGP; ThailandTHA; Vietnam-VNM

Outdegree centrality shows how much a node is connected to others through outgoing ties. Maps generated using Gephi Network Mapping 
Figure 3: Weighted betweenness centrality of the ASEAN countries (2003 - 2016)

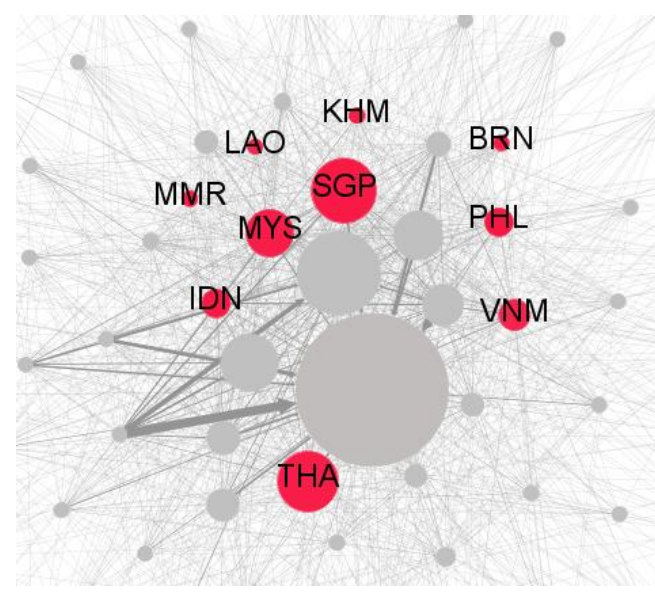

Global

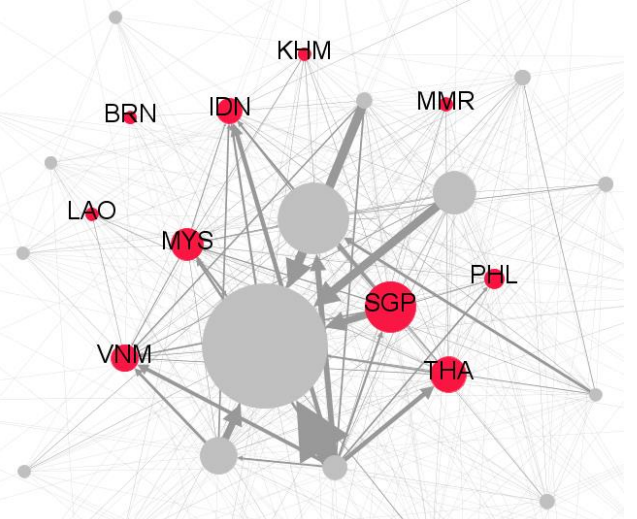

Regional

Source: Authors, 2020

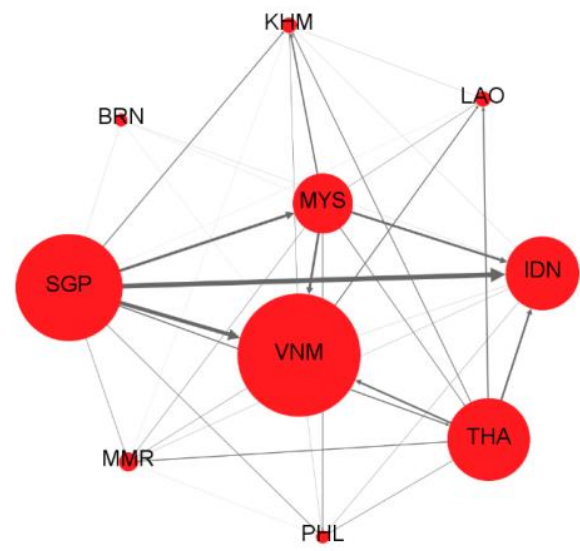

Local

\section{Figure legend}

The circles with codes represent the ASEAN countries connected by FDI flows. The size of the circle is weighted and is proportional to the betweenness of the countries (nodes).

Country Codes: Brunei Darussalam-BRN; Cambodia-KHM; Indonesia-IDN; Lao PDRLAO; Malaysia-MYS; Myanmar-MMR;

Philippines-PHL; Singapore-SGP; ThailandTHA; Vietnam-VNM

Betweenness centrality shows how important a node is in terms of connecting other nodes.

Maps generated using Gephi Network Mapping 
In a final cross-match between all the networks (Figure one, two and three), the investment ties at a global scale are found to be denser followed by regional and local scale. Also, FDI ties linking ASEAN countries to others is found to be highly disproportionate with most of the linkages connecting a few major nations in the region in terms of both indegree and outdegree. However, the dispersion is higher for indegree compared to outdegree, as more ASEAN nations appear to attract FDI. Nonetheless, Singapore is the only standout nation in terms of outward linkages throughout the global, regional and local networks. Diverging characteristics of the indegree and outdegree positionality of the countries across networks of different scales is also noticed. For instance, Singapore has a strong indegree only in the global network but its outdegree remains strong and consistent in all three scales. On the contrary, Indonesia has moderate outward FDI ties (outdegree) directed towards global, regional and local nations despite its dominant indegree in all scales of integration. From this, it can be said that countries like Singapore holds power in the global economy and are also dependent to their global partners, but at a regional and local scales, Singapore exerts economic power on others through outward FDI but is less dependent on the Asian and ASEAN member nations. For countries like Indonesia, it can be said that it is dependent upon a wide array of nations irrespective of geographical scale, be it global, regional or local but has limited economic influence over others.

\subsection{Positionality and Economic Growth}

The second part of this study concerns whether the positionality of nations in a network converts to improved economic performance and if the positionality at different scales has differential impacts on their performance. Using panel data covering 14 years (2003-2016) for the ten ASEAN countries, three fixed-effect regressions were conducted (refer Table 4 attached in the annex for the summary of data). Table three below shows the effect of five different network measures of centrality on the dependent variable: economic growth (GDP). The analysis includes three models: Model 1 at a global scale, Models 2 at a regional scale and Model 3 at a local scale. 
Table 3: Regression results

\begin{tabular}{|c|c|c|c|c|c|}
\hline \multicolumn{2}{|c|}{ (Model 1) } & \multicolumn{2}{|c|}{ (Model 2) } & \multicolumn{2}{|c|}{ (Model 3) } \\
\hline $\begin{array}{l}\text { Global } \\
\text { Network }\end{array}$ & $\begin{array}{l}\text { Economic } \\
\text { Growth }\end{array}$ & $\begin{array}{l}\text { Regional } \\
\text { Network }\end{array}$ & $\begin{array}{l}\text { Economic } \\
\text { Growth }\end{array}$ & $\begin{array}{l}\text { Local } \\
\text { Network }\end{array}$ & $\begin{array}{l}\text { Economic } \\
\text { Growth }\end{array}$ \\
\hline \multirow[t]{2}{*}{ Indegree } & $1.19 \mathrm{e}-05^{* *}$ & Indegree & $3.43 \mathrm{e}-05^{* *}$ & Indegree & $3.65 \mathrm{e}-05^{* *}$ \\
\hline & $(0.00)$ & & $(0.00)$ & & $(0.00)$ \\
\hline \multirow[t]{2}{*}{ Outdegree } & $4.67 \mathrm{e}-05^{* *}$ & Outdegree & $5.30 \mathrm{e}-05 * * *$ & Outdegree & $4.94 \mathrm{e}-05$ \\
\hline & $(0.00)$ & & $(0.00)$ & & $(0.00)$ \\
\hline \multirow[t]{2}{*}{ Closeness } & 0.0538 & Closeness & 0.00546 & Closeness & 0.0342 \\
\hline & $(0.06)$ & & $(0.09)$ & & $(0.07)$ \\
\hline \multirow[t]{2}{*}{ Betweenness } & 0.000108 & Betweenness & -0.00107 & Betweenness & -0.00825 \\
\hline & $(0.00)$ & & $(0.00)$ & & $(0.01)$ \\
\hline \multirow[t]{2}{*}{ Eigenvector } & 0.405 & Eigenvector & 0.401 & Eigenvector & 0.103 \\
\hline & $(0.27)$ & & $(0.24)$ & & $(0.22)$ \\
\hline \multirow[t]{2}{*}{$\begin{array}{c}\text { Enrolment in } \\
\text { tertiary } \\
\text { education }\end{array}$} & $0.0281 * * *$ & $\begin{array}{c}\text { Enrolment in } \\
\text { tertiary } \\
\text { education }\end{array}$ & $0.0278 * * *$ & $\begin{array}{c}\text { Enrolment in } \\
\text { tertiary } \\
\text { education }\end{array}$ & $0.0301 * * *$ \\
\hline & $(0.01)$ & & $(0.00)$ & & $(0.01)$ \\
\hline \multirow[t]{2}{*}{ Employment rate } & 0.0356 & $\begin{array}{l}\text { Employment } \\
\text { rate }\end{array}$ & 0.0287 & $\begin{array}{l}\text { Employment } \\
\text { rate }\end{array}$ & 0.0326 \\
\hline & $(0.02)$ & & $(0.02)$ & & $(0.02)$ \\
\hline \multirow[t]{2}{*}{$\begin{array}{r}\text { Corruption } \\
\text { control }\end{array}$} & 0.162 & $\begin{array}{r}\text { Corruption } \\
\text { control }\end{array}$ & 0.146 & $\begin{array}{r}\text { Corruption } \\
\text { control }\end{array}$ & 0.185 \\
\hline & $(0.09)$ & & $(0.09)$ & & $(0.13)$ \\
\hline \multirow[t]{2}{*}{$\begin{array}{l}\text { Shipping } \\
\text { connectivity }\end{array}$} & $0.00835^{* * *}$ & $\begin{array}{l}\text { Shipping } \\
\text { connectivi } \\
\text { ty }\end{array}$ & $0.00794 * * *$ & $\begin{array}{l}\text { Shipping } \\
\text { connectivi } \\
\text { ty }\end{array}$ & $0.00739 * *$ \\
\hline & $(0.00)$ & & $(0.00)$ & & $(0.00)$ \\
\hline \multirow[t]{2}{*}{$\begin{array}{r}\text { Population } \\
\text { density }\end{array}$} & $0.0128 * * *$ & $\begin{array}{r}\text { Population } \\
\text { density }\end{array}$ & $0.0141 * * *$ & $\begin{array}{r}\text { Population } \\
\text { density }\end{array}$ & $0.0158 * * *$ \\
\hline & $(0.00)$ & & $(0.00)$ & & $(0.00)$ \\
\hline \multirow[t]{2}{*}{ Inflation rate } & 0.00467 & Inflation rate & 0.00561 & Inflation rate & 0.00538 \\
\hline & $(0.00)$ & & $(0.00)$ & & $(0.00)$ \\
\hline \multirow[t]{2}{*}{ Constant } & 2.458 & Constant & $2.765^{*}$ & Constant & 2.456 \\
\hline & $(1.44)$ & & $(1.33)$ & & $(1.35)$ \\
\hline Observations & 101 & Observations & 101 & Observations & 101 \\
\hline R-squared & 0.807 & R-squared & 0.821 & R-squared & 0.781 \\
\hline Number of ID & 10 & Number of ID & 10 & Number of ID & 10 \\
\hline
\end{tabular}

Robust standard errors in parentheses

$* * * \mathrm{p}<0.01, * * \mathrm{p}<0.05, * \mathrm{p}<0.1$

Source: Authors, 2020 
Model 1 examines the centralities of the ASEAN countries in the network formed by the investment linkages between ASEAN and countries world-wide (global) influencing economic growth and demonstrates that the indegree ( $\beta=$ $1.19 \mathrm{e}-05$, $\mathrm{p}$-value $=0.05)$ and outdegree $(\beta=4.67 \mathrm{e}-05$, $\mathrm{p}$-value $=0.05)$ centrality have a significant positive effect on economic growth. With each additional incoming investment tie, the predicted probability of an increase in the GDP is $1.19 \mathrm{e}-05$ percentage and with one unit increase in the outward FDI connectivity, the GDP is likely to grow by $4.67 \mathrm{e}-05$ percentage. Betweenness, closeness and eigenvector measures of centrality were not found to have a statistically significant effect on economic growth.

Model 2 examines the centralities of the ASEAN countries in the network formed by investment linkages between Asian and ASEAN countries (regional) influencing economic growth and demonstrates that the indegree $(\beta=3.43 \mathrm{e}-05$, $\mathrm{p}$ value $=0.05)$ and outdegree $(\beta=5.30 \mathrm{e}-05, \mathrm{p}$-value $=0.01)$ centrality have a significant positive effect on economic growth. With each additional incoming investment tie from a regional partner, the predicted probability of an increase in the GDP is $3.43 \mathrm{e}-05$ percentage and with one unit increase in the outward FDI connectivity, the GDP is likely to grow by $5.30 \mathrm{e}-05$ percentage. No other centrality measures were found to have a statistically significant effect on economic growth.

Model 3 examines the centralities of the ASEAN countries in the network formed by intra-ASEAN investment linkages (local) influencing economic growth and demonstrates that only indegree $(\beta=3.65 \mathrm{e}-05$, $\mathrm{p}$-value $=0.05)$ centrality have a significant positive effect on economic growth. With each additional incoming investment tie, the predicted probability of an increase in the GDP is $3.65 \mathrm{e}-05$ percentage. No other centrality measures were found to have a statistically significant effect on economic growth. As claimed by the broader literature, indicators of human capital (enrollment in tertiary education), infrastructural development (linear shipping connectivity) and population density (demography) included in the model as control variables were also found to have a statistically significant effect on economic growth.

\section{DisCUSSIONS}

The findings of this study show that the investment ties of ASEAN countries at a global scale are denser followed by regional and local scale, supporting (Friedmann 1986) which claims that places have become economically disconnected from their local geographies with growing global connections. Further, the results illustrate the persistence of a highly polarized investment 
network between ASEAN countries and their allies, dominated by the links between few key ASEAN countries and their global, regional and local investment partners. Incoming investment links, as captured by indegree centrality, remain significant for five out of ten countries on the global scale, and four and two in the regional and local scale respectively. In terms of outdegree, Singapore is the only standout nation in the network in all three scales. This remains concomitant to extant networks literature, which has also highlighted on the disproportionate geographical distribution of corporate networks (Wall and Knaap 2011, Carroll 2007) resulting in the concentration of investments links between few key nations (Driffield and Love 2005). In fact (Wall et al. 2011) claim that high interconnectedness is found only between some countries and most corporate links start from and are directed to the 'happy few'.

From the results, it is also found that the linkages of ASEAN nations based on indegree and outdegree are divergent in characteristics. While substantial outdegree is noticed only for Singapore, indegree instead is found to be comparably more dispersed over five nations. This is consistent with (Wall 2009) that posit, the economic power of nations as shown by outdegree in a network occurs in limited developed places (cities) and inward linkages are more spread over many places. Furthermore, concerning the positionality of ASEAN countries across networks of different scale, the results show that some of the nations do tend to occupy altered positions in different network scales as highlighted by (van der Knaap 2006). For instance, the results show Vietnam's betweenness is not high in the global and regional network, but it holds the most dominant betweenness position in the local network. Likewise, a noticeable shift is seen in the indegree positionality of Singapore. While it has a strong indegree position in the global network, its positionality in the regional network gets feebler, which further reduces in the local network.

A weak association is found between indegree and outdegree positionality of the ASEAN nations opposed to (Alderson and Beckfield 2004), showing nations with higher outdegree do not necessarily have higher indegree and vice versa. This is visible through Indonesia's indegree position in all scales of integration, which is the foremost among all the ASEAN nations even with its moderate outdegree position. Similarly, at a regional and local scale, Singapore has a moderate indegree regardless of its stronger outdegree centrality. Unlike (Wall 2009), which suggest places with strong outdegree is also likely to take strong betweenness position in a network, no robust association is detected between outdegree and betweenness. While it appears to be proper in case of Singapore, it is contradictory for Vietnam as it is noticed that 
even with its lower outdegree, it takes a central intermediary role in the intrainvestment links taking place between ASEAN nations.

The results of the regression analysis show that indegree centrality of ASEAN countries in all spatial scales has a significant positive effect on economic growth. On the other hand, the centrality of the ASEAN nations in terms of outdegree is found to share a significant positive correlation with economic growth only at a global and regional scale. Generally, the result is consistent with (Wall 2009), showing a strong positive cohesion between indegree and outdegree with national GDP which was competitiveness in the case of former. Nonetheless, Wall's assessment on the relationship was deprived of a scalar viewpoint. In this study, we do not find a strong correlation between outdegree at a local scale and economic growth. Further, the results of this study contradict to (Pain et al. 2016) which found no generalized relationship between city connectivity and economic growth for US and European cities. However, the networks explored and the context of both studies are different. While (Pain et al. 2016) concerns, corporate, air and maritime connectivity of European and US cities, this study explored FDI networks of the ASEAN countries. Also, in the former, the number of ties between cities is used as a general indicator of network connectivity, but this study analysed the relationship based on positionality using five different network centrality measures.

In comparison to numerous FDI and economic growth studies which are based on non-relational data, the results of this study provide a similar perspective on inward FDI, showing that incoming FDI ties (indegree) from global, regional and local partners irrespective of their geographic proximity (scale) is likely to augment economic growth of the ASEAN nations. However, opposed to majority extant studies which provide a notion that outward FDI (outdegree) to anyplace regardless of geographic scale will boost the economy, this study finds that outward FDI (outdegree) to global and regional allies may be more beneficial than local partners. This relates to (Makino et al. 2002) which assert that local firms by investing abroad will get access to fresh assets, know-how, natural resources and markets that might not be available locally contributing to their economic performance. Similarly, outward FDI according to (Goh et al. 2013) allows overcoming local resource limitation and expands access to international markets raising profit opportunities of the host market. 


\section{5: CONCLUSIONS}

First, this paper explored the positionality of ten ASEAN nations in their global, regional and local investment (FDI) networks using three network measure of centrality. Second, the relationship between network positionality in different scales of integration and economic performance were examined (2003 and 2016) for the Southeast Asian countries.

This article contributes to the converging studies on networks and international economics, serving to plot an understanding of positionality and how it might impact on the economic performance of nations from a scalar perspective. It contributes to the understanding of how positionality can be ascribed to nations at spatial scales ranging from the local to the world region. Members of the same ASEAN region typically are positioned differently concerning one another, both within the region and with respect to the rest of Asia or globally, and such differences may exist among cities/nations of any territory. A nation's positionality varies and depends on the scale at which it is examined.

The importance of studying different scales of economic integration is reflected in the findings, that no single scale analysis provides a complete understanding of the actors in the network and their associated impacts. In a similar note, the findings of the study are suggestive of the need for nations to adopt multiple scales of interventions and policy to seize desired positions at different scales of integration to achieve higher growth. Further, paying attention to positionality based on different measures of centrality can also provide deeper insights into the role of each nation within a network supporting strategies to guide or alter its trajectory.

Although the analysis in this study has not demonstrated causality between positionality and economic growth, it has been shown that there is a strong positive cohesion between network measures of indegree in all scales of integration and, global and regional outdegree with the economic performance of nations. In this light, it is arguable that the integration of nations with other nations in the world economic system through resources like inward and outward investments appear to be significant to the growth of nations. Hence, administrators and policymakers should not only consider the forces that are found 'within' national boundaries but it is also essential to consider external relationships and connectivity to achieve higher growth. As it stands, only a few countries in Southeast Asia holds strong positions in the network as reflected by their indegree and outdegree centralities, hence, conditions to further the investment attractiveness for inward FDI ties and 
enhancing global and regional outward investment linkages appear to be a potent strategy to further economic growth of the ASEAN nations.

The limitation of the first part of this study is that the work is particularly descriptive. However, combined with theoretical arguments, this study does offer certain insights into the network characteristics of the ASEAN countries. Further, it is worth mentioning that this study evaluated FDI networks which reveals only a partial view of the connections of the ASEAN. Economic networks like FDI are likely to be one of the most important networks to study, however, in an intertwined society, other types of economic, social and political networks may also play significant roles. Hence, we recommend future research may focus on other important networks to refine the understanding of network positionality and their associated socio-economic impacts. Last, the empirical model employed in this study considers that the variables are exogenous. Thus, the potential simultaneity bias should be addressed in future research. 


\section{REFERENCES}

1. Alderson, A.S. and J. Beckfield (2004) 'Power and Position in the World City System', American Journal of sociology 109(4): 811-851.

2. Ali, I. and E.M. Pernia (2003) 'Infrastructure and Poverty Reduction-what is the Connection?'.

3. Amin, A. and S. Graham (1999) 'Cities of Connection and Disconnection', Unsettling cities: 7-38.

4. Berry, B.J. (1964) 'Cities as Systems within Systems of Cities', Papers in regional science 13(1): 146-163.

5. Blomstrom, M. and A. Kokko (2001) 'Foreign Direct Investment and Spillovers of Technology', International Journal of Technology Management 22(5-6): 435-454.

6. Borensztein, E., J. De Gregorio and J. Lee (1998) 'How does Foreign Direct Investment Affect Economic Growth?', Journal of International Economics 45(1): 115-135.

7. Borgatti, S.P. (2005) 'Centrality and Network Flow', Social networks 27(1): 55-71.

8. Camagni, R.P. and C. Salone (1993) 'Network Urban Structures in Northern Italy: Elements for a Theoretical Framework', Urban Studies 30(6): 1053-1064.

9. Carroll, W.K. (2007) 'Global Cities in the Global Corporate Network', Environment and Planning A 39(10): 2297-2323.

10. Castells, M. (1996) 'The Rise of the Network Society (Malden, MA', Blackwell 373: 307-341.

11. Clark, G., T. Moonen and J. Couturier (2013) 'The Business of Cities 2013'150.

12. Clark, T.N., R. Lloyd, K.K. Wong and P. Jain (2002) 'Amenities Drive Urban Growth', Journal of urban affairs 24(5): 493-515.

13. Coe, N.M., M. Hess, H.W. Yeung, P. Dicken and J. Henderson (2004) 'Globalizing'regional Development: A Global Production Networks Perspective', Transactions of the Institute of British geographers 29(4): 468-484.

14. Derudder, B. and P. Taylor (2005) 'The Cliquishness of World Cities', Global Networks 5(1): 71-91.

15. Dicken, P. (2004) 'Geographers and 'globalization':(Yet) another Missed Boat?', Transactions of the institute of British Geographers 29(1): 5-26.

16. Dicken, P., P.F. Kelly, K. Olds and H. Wai-Chung Yeung (2001) 'Chains and Networks, Territories and Scales: Towards a Relational Framework for Analysing the Global Economy', Global networks 1(2): 89-112.

17. Driffield, N. and J.H. Love (2005) 'Intra-Industry Foreign Direct Investment, Uneven Development and Globalisation: The Legacy of Stephen Hymer', Contributions to Political Economy 24(1): 55-78.

18. Friedmann, J. (1986) 'The World City Hypothesis', Development and change 17(1): 69-83. 
19. Goh, S.K., K.N. Wong and S.Y. Tham (2013) 'Trade Linkages of Inward and Outward FDI: Evidence from Malaysia', Economic Modelling 35: 224-230.

20. Hall, P.G. (1966) The World Cities. Weidenfeld and Nicolson London.

21. Henderson, J., P. Dicken, M. Hess, N. Coe and H.W. Yeung (2002) 'Global Production Networks and the Analysis of Economic Development', Review of international political economy 9(3): 436-464.

22. Hennemann, S. and B. Derudder (2014) 'An Alternative Approach to the Calculation and Analysis of Connectivity in the World City Network', Environment and Planning B: Planning and Design 41(3): 392-412.

23. Hofmann, P. (2013) The Impact of International Trade and FDI on Economic Growth and Technological Change. Springer Science \& Business Media.

24. Kitson, M., R. Martin and P. Tyler (2004) 'Regional Competitiveness: An Elusive Yet Key Concept?', Regional Studies 38(9): 991-999.

25. Le Blanc, D., C. Freire, R. Jussila and T. Vaturi (2016) 'Chapter 2: The InfrastructureInequality-Resilience Nexus', Global Sustainable Development Report .

26. Makino, S., C. Lau and R. Yeh (2002) 'Asset-Exploitation Versus Asset-Seeking: Implications for Location Choice of Foreign Direct Investment from Newly Industrialized Economies', Journal of International Business Studies 33(3): 403-421.

27. Neal, Z. (2013) 'Does World City Network Research Need Eigenvectors?', Urban Studies 50(8): 1648-1659.

28. Neal, Z. (2011) 'Differentiating Centrality and Power in the World City Network', Urban Studies 48(13): 2733-2748.

29. Nguyen, H.T., G. Duysters, J.H. Patterson and H. Sander (2009) 'Foreign direct investment absorptive capacity theory', Georgia Institute of Technology.

30. Pain, K., G. Van Hamme, S. Vinciguerra and Q. David (2016) 'Global Networks, Cities and Economic Performance: Observations from an Analysis of Cities in Europe and the USA', Urban Studies 53(6): 1137-1161.

31. Ruhnau, B. (2000) 'Eigenvector-Centrality—a Node-Centrality?', Social networks 22(4): 357-365.

32. Sassen, S. (1994) Global City. Princeton University Press New York, London, Tokyo.

33. Schwab, K. (2014) The Global Competitiveness Report 2014-2015. Geneva: World Economic Forum.

34. Schweitzer, F., G. Fagiolo, D. Sornette, F. Vega-Redondo, A. Vespignani and D.R. White (2009) 'Economic Networks: The New Challenges', Science (New York, N.Y.) 325(5939): 422-425.

35. Sheppard, E. (2002) 'The Spaces and Times of Globalization: Place, Scale, Networks, and Positionality', Economic geography 78(3): 307-330.

36. Shi, S., R. Wall and K. Pain (2019) 'Exploring the Significance of Domestic Investment for Foreign Direct Investment in China: A City-Network Approach', Urban Studies 56(12): 2447-2464. 
37. Sigler, T.J. and K. Martinus (2017) 'Extending Beyond 'world Cities' in World City Network (WCN) Research: Urban Positionality and Economic Linkages through the Australia-Based Corporate Network', Environment and Planning A: Economy and Space 49(12): 2916-2937.

38. Smith, D.A. and M.F. Timberlake (2001) 'World City Networks and Hierarchies, 1977-1997: An Empirical Analysis of Global Air Travel Links', American Behavioral Scientist 44(10): 1656-1678.

39. Taylor, P. (2004) 'World City Network: A Global Urban Analysis (Routledge, London).'.

40. Toly, N., S. Bouteligier, G. Smith and B. Gibson (2012) 'New Maps, New Questions: Global Cities Beyond the Advanced Producer and Financial Services Sector', Globalizations 9(2): 289-306.

41. van der Knaap, G. (2006) 'Urban Network Development Under Conditions of Uncertainty', Cities in Globalization: Practices, Policies and Theories: 84.

42. Wall, R. (2009) Netscape: Cities and Global Corporate Networks.

43. Wall, R.S., M.J. Burger and G. Van der Knaap (2011) 'The Geography of Global Corporate Networks: The Poor, the Rich, and the Happy Few Countries', Environment and Planning A 43(4): 904-927.

44. Wall, R.S. and G.A.v.d. Knaap (2011) 'Sectorial Differentiation and Network Structure within Contemporary Worldwide Corporate Networks', Economic Geography 87(3): 267-308.

45. Wasserman, S. and K. Faust (1994) Social Network Analysis: Methods and Applications. Vol. 8. Cambridge university press.

46. Whitley, R. (1998) 'Internationalization and Varieties of Capitalism: The Limited Effects of Cross-National Coordination of Economic Activities on the Nature of Business Systems', Review of international political economy 5(3): 445-481. 


\section{ANNEX}

Table: Summary of the data

\begin{tabular}{|c|c|c|c|c|c|}
\hline Indicator & $\begin{array}{l}\text { No. of } \\
\text { observa } \\
\text { tions }\end{array}$ & Means & $\begin{array}{r}\text { Standard } \\
\text { Devi } \\
\text { ation }\end{array}$ & Min. & Max. \\
\hline $\begin{array}{l}\text { GDP per capita } \\
\text { (USD) }\end{array}$ & 140 & 9837 & 15363 & 219 & 56336 \\
\hline Global In-degree & 140 & 5112 & 4512 & 0 & 17071 \\
\hline Global Out-degree & 140 & 1546 & 2871 & 0 & 15059 \\
\hline Global closeness & 140 & 0.37 & 0.25 & 0 & 1 \\
\hline Global betweenness & 140 & 66.5 & 87 & 0 & 474.8 \\
\hline Global eigenvector & 140 & 0.64 & 0.29 & 0 & 1 \\
\hline Regional In-degree & 140 & 2507 & 2547 & 0 & 10446 \\
\hline Regional Out-degree & 140 & 1137 & 2285 & 0 & 11345 \\
\hline $\begin{array}{l}\text { Regional closeness } \\
\text { Regional }\end{array}$ & 140 & 0.38 & 0.26 & 0 & 1 \\
\hline betweenness & 140 & 21.1 & 27.5 & 0 & 96.5 \\
\hline Regional eigenvector & 140 & 0.64 & 0.28 & 0 & 1 \\
\hline Local In-degree & 140 & 854 & 1155 & 0 & 6213 \\
\hline Local Out-degree & 140 & 854 & 1604 & 0 & 10626 \\
\hline Local closeness & 140 & 0.48 & 0.37 & 0 & 1 \\
\hline Local betweenness & 140 & 2.65 & 3.8 & 0 & 13.9 \\
\hline $\begin{array}{l}\text { Local eigenvector } \\
\text { Population density }\end{array}$ & 140 & 0.66 & 0.28 & 0 & 1 \\
\hline (people $\left./ \mathrm{km}^{2}\right)$ & 140 & 59.1 & 69.2 & 0.35 & 261.1 \\
\hline Inflation rate $(\%)$ & 140 & 5.4 & 6.5 & -22.1 & 23.6 \\
\hline $\begin{array}{l}\text { Enrolment in tertiary } \\
\text { education }(\%, \\
15+)\end{array}$ & 101 & 24.4 & 12.4 & 2.8 & 52.7 \\
\hline $\begin{array}{l}\text { Employment to } \\
\text { population ratio } \\
(\%)\end{array}$ & 140 & 69.2 & 7.8 & 57.7 & 85.2 \\
\hline $\begin{array}{l}\text { Control of corruption } \\
\text { Liner shipping }\end{array}$ & 130 & -0.29 & 1.03 & -1.69 & 2.41 \\
\hline connectivity & 117 & 35.2 & 35.1 & 2.47 & 122.7 \\
\hline
\end{tabular}

Source: Authors, 2020 